\title{
Perbedaan khasiat antibakteri bahan irigasi antara hidrogen peroksida 3\% dan infusum daun Sirih 20\% terhadap bakteri mix
}

\author{
(The comparison of the antibacterial effect of irrigation solutions hydrogen \\ peroxyde $3 \%$ and piper betle folium infusum $20 \%$ to bacterial mix)
}

\author{
Dian Agustin W \\ Bagian Konservasi Gigi \\ Fakultas Kedokteran Gigi Universitas Airlangga \\ Surabaya - Indonesia
}

\begin{abstract}
Piper betle folium was Indonesian's traditional medicinal herb. The most important element in its was phenol with has antibacterial effect. $\mathrm{H}_{2} \mathrm{O}_{2} 3 \%$ was commonly used because readily available, can lift up debris from root canal preparation. The purpose of this study was to determine the antibacterial effect of two solutions: hydrogen peroxide $3 \%$ and piper betle folium infusum $20 \%$ to bacterial mix invitro. The twenty specimens are divided into two groups. The result is statistically analyzed using Wilcoxon man whitney test. This study showed that piper betle folium infusum $20 \%$ had greater antibacterial effect than $\mathrm{H}_{2} \mathrm{O}_{2} 3 \%$ solution.
\end{abstract}

Key words: piper betle folium, $\mathrm{H}_{2} \mathrm{O}_{2} 3 \%$, antibacterial effect

Korespondensi (correspondence): Dian Agustin W, Bagian Konservasi Gigi, Fakultas Kedokteran Gigi Universitas Airlangga. Jln. Mayjen. Prof. Dr. Moestopo No. 47 Surabaya 60132, Indonesia.

\section{PENDAHULUAN}

Pada penelitian awal ditemukan beberapa spesies di antaranya streptococci, micrococci, dan sejumlah kecil bakteri anaerob pada infeksi saluran akar maupun penyakit periradikular. Bakteri anaerob meliputi $90 \%$ dari bakteri penyebab infeksi saluran akar. ${ }^{1}$ Berdasarkan temuan tersebut, ternyata penyebab infeksi saluran akar tidak hanya satu macam bakteri tetapi berbagai macam bakteri yang terlibat termasuk organisme anaerob seperti Porphyromonas, Bacterioides Gingivalis, Phorphyromonas Bacterioides Endodontalis, dan Prevotella Bacterioides Buccae yang dinamakan Bacterioides Spesies.

Tahapan penting dalam perawatan saluran akar gigi yang terinfeksi adalah preparasi, sterilisasi dan pengisian. ${ }^{2}$ Preparasi saluran akar gigi akan menunjang proses sterilisasi dan menghasilkan pengisian yang baik sehingga didapatkan hasil yang maksimal. ${ }^{3}$ Pada tahap preparasi diperlukan bahan irigasi saluran akar yang bertujuan menghilangkan jaringan nekrotik, tumpukan serpihan dentin dan membasahi saluran akar gigi sehingga mempermudah dalam pelaksanaan preparasi serta pengurangan jumlah mikroorganisme di dalam saluran akar kemudian sisa bakteri dimatikan dengan obatobatan..$^{3,4}$

Bahan yang dapat digunakan untuk irigasi antara lain hidrogen peroksidase $\left(\mathrm{H}_{2} \mathrm{O}_{2}\right) 3 \%, \mathrm{NaOCl}, 3 \%$, EDTA $15 \%$, Chlorhexidine, Akuades. Hidrogen peroksidase $\left(\mathrm{H}_{2} \mathrm{O}_{2}\right) 3 \%$ merupakan salah satu bahan irigasi yang sering digunakan karena mudah didapat, dapat mengangkat kotoran dari hasil preparasi saluran akar. Penggunaan larutan $\mathrm{H}_{2} \mathrm{O}_{2} 3 \%$ diikuti dengan larutan irigasi lainnya misal akuades, karena sisa oksigen peroksida dalam saluran akar harus dinetralisir atau dihilangkan. Oksigen yang terjadi akan menghasilkan gelembung udara kemudian akan membantu pengeluaran kotoran secara efektif. Walaupun demikian sekarang metode ini tidak dianjurkan karena oksigen yang tersebut dapat terbawa keluar menuju jaringan periapikal dan menimbulkan empisema. ${ }^{4}$ Hidrogen peroksidase $\left(\mathrm{H}_{2} \mathrm{O}_{2}\right)$ $3 \%$ harus dibersihkan dari kavitas gigi sebelum kavitas ditutup, karena evaluasi oksigen setelah penutupan dapat mendorong kotoran dan mikroorganisme ke jaringan periapikal. ${ }^{5}$ Semula dikatakan bahwa $\mathrm{H}_{2} \mathrm{O}_{2} 3 \%$ dianggap dapat mengeluarkan debris karena mempunyai aksi nascent berbusa namun tidak terbukti karena ternyata peningkatan debridement tidak terjadi. Hal ini disebabkan oleh terbatasnya daya antibakteri dari bahan ini. ${ }^{4}$

Di Indonesia terdapat tanaman sirih, yang khasiat daunnya telah banyak digunakan 6,7,8 efek astringent bahan ini, telah diketahui sebagai obat kumur, tidak menimbulkan iritasi selaput lendir rongga mulut. Pada konsentrasi 20\% bekerja lebih baik terhadap Streptococcus Viridans. ${ }^{6,9,10}$

Dalam daun sirih 100 gram terdapat kandungan: ${ }^{11}$ air $85,4 \mathrm{mg}$; protein $3,1 \mathrm{mg}$; karbohidrat $6,1 \mathrm{mg}$; serat 2,3 mg; yodium 3,4 mg; mineral 2,3 mg; kalsium $230 \mathrm{mg}$; fosfor $40 \mathrm{mg}$; besi ion $3,5 \mathrm{mg}$; karoten (vitamin A) $9600 \mathrm{iu}$, kalium nitrat 0,26-0,42 mg; tiamin $70 \mathrm{mg}$; riboflavin $30 \mathrm{mg}$; asam nikotinal $0,7 \mathrm{mg}$; vitamin C $5 \mathrm{mg}$; kanji 1,0-1,2\%; gula non reduksi $0,6-2,5 \%$; gula reduksi 
1,4-3,2\%. Sedangkan minyak atsirinya terdiri dari: alilkatekol 2,7-4,6\%; kadinen 6,7-9,1\%; karvakol 2,2-4,8\%; kariofilen 6,2-11,9\%; kavibetol 0,0-1,2\%; kavikol 5,1-8,2\%; sineol 3,6-6,2\%; eugenol 26,8-42,5\%; eugenol metil eter $26,8-15,58 \%$; pirokatekin.

Penelitian ini bertujuan untuk mengetahui perbedaan khasiat antibakteri bahan irigasi antara $\mathrm{H}_{2} \mathrm{O}_{2} 3 \%$ dan infusum daun sirih $20 \%$ terhadap bakteri mix. Hasil penelitian ini diharapkan dapat meningkatkan manfaat daun sirih sebagai tanaman obat tradisionil.

\section{BAHAN DAN METODE}

Rancangan penelitian yang digunakan adalah aksperimental laboratories. Bahan yang digunakan dalam penelitian ini adalah infusum daun sirih $20 \%$ dan $\mathrm{H}_{2} \mathrm{O}_{2}$ $3 \%$. Infusum daun sirih $20 \%$ didapatkan dari daun sirih yang segar dipotong-potong dengan diameter kurang lebih $0,5 \mathrm{~cm}$, kemudian dikeringkan di bawah sinar matahari sampai berwarna kehitam-hitaman dan rapuh (mudah diremas). Daun sirih yang telah kering dihaluskan dengan menggunakan blender untuk mendapatkan bubuk daun sirih. Untuk mendapatkan infusum ambil 10 gram bubuk daun sirih ditambah akuades $100 \mathrm{cc}$ dididihkan selama 15 menit kemudian diambil 80cc dididihkan lagi sampai mendapat 40cc. Sedangkan sediaan $\mathrm{H}_{2} \mathrm{O}_{2} 3 \%$ didapatkan dari apotik yang telah tersedia dalam sediaan botol.

Untuk mendapatkan bakteri dalam media Brain Heart Infusion Broth (BHIB), pertama masukkan paper poin steril ke dalam saluran akar gigi untuk mendapatkan bakteri mix dengan diagnosa nekrosis pulpa selama 1menit. Paper poin yang telah dimasukkan dikeluarkan dan dimasukkan ke dalam tabung media yang mengandung BHIB kemudian dimasukkan ke dalam inkubator selama 24 jam. Blood Agar yang telah jadi dibagi menjadi 4 zona, kemudian dilakukan pemberian bakteri yang telah dibiakkan di dalam BHIB. Selanjutnya diberi perlakuan penetesan $\mathrm{H}_{2} \mathrm{O}_{2} 3 \%$ dan penetesan infusum daun sirih dengan menggunakan mikro pipet pada kertas serap masing-masing satu tetes (10 microliter) yang telah ditaruh di atas Blood Agar. Kemudian dimasukkan ke dalam inkubator selama 48 jam. Selanjutnya untuk mengetahui daya hambatnya dilakukan pengukuran zona inhibisi, zona hambatan tersebut ditandai dengan adanya daerah jernih di sekeliling kertas serap. Makin besar zona hambatan menunjukkan bahwa khasiat antibakteri bahan tersebut makin kuat. Cara pengukuran dengan menggunakan kaliper dengan mengukur panjang dan lebar kertas serap ditambah daerah jernih kemudian dibagi dua.

\section{HASIL}

Analisis data menggunakan uji Wilcoxon man whitney test. Melihat perbedaan antara diameter zona hambatan pertumbuhan bakteri mix oleh bahan irigasi $\mathrm{H}_{2} \mathrm{O}_{2} 3 \%$ dan infusum daun sirih 20\% (tabel. 1)
Tabel 1. Rerata diameter zona hambatan pertumbuhan bakteri mix dengan hidrogen peroksida $3 \%$ dan infusum daun sirih $20 \%$

\begin{tabular}{lcccc}
\hline \multicolumn{1}{c}{ Bahan } & $\mathrm{n}$ & $\begin{array}{c}\overline{\mathrm{X}} \\
(\mathrm{mm})\end{array}$ & $\mathrm{SD}$ & $\mathrm{p}$ \\
\hline $\mathrm{H}_{2} \mathrm{O}_{2} 3 \%$ & 10 & 0,8 & 0,48 & $0,001^{*}$ \\
Infusum daun sirih $20 \%$ & 10 & 8,53 & 1,04 & $(<0,05)$ \\
\hline
\end{tabular}

Keterangan: * berbeda bermakna

Dari hasil uji Wilcoxon beda diameter zona hambatan pertumbuhan bakteri mix oleh bahan irigasi hidrogen peroksida $3 \%$ dan infusum daun sirih $20 \%$ diperoleh nilai $\mathrm{p}=0,001$ yang berarti terdapat perbedaan bermakna antara besar diameter zona hambatan bakteri mix oleh bahan irigasi hidrogen peroksida 3\% dan infusum daun sirih $20 \%$.

\section{PEMBAHASAN}

Pada tahap preparasi diperlukan bahan irigasi, diharapkan semua kotoran yang berada di dalamnya akan ikut mengalir keluar bersama dengan cairan irigasi. Bahan irigasi saluran akar sebaiknya bersifat antiseptik yaitu dapat merusak, dapat menghambat reproduksi atau metabolisme mikroba dan sekaligus menstrerilkan saluran akar. ${ }^{2,3,4}$ Adapun syarat bahan antiseptik saluran akar adalah mampu membunuh mikroba organisme, mempunyai efektifitas yang cepat mampu mengadakan penetrasi yang dalam, tetap efektif dengan adanya bahan organik, tidak merubah warna gigi, secara kimia bersifat stabil, tidak berbau dan tidak berasa, ekonomis. ${ }^{2,3,4}$

Hasil penelitian menunjukkan bahwa diameter zona hambatan bakteri mix oleh infusum daun sirih $20 \%$ lebih besar dari hidrogen peroksida $3 \%$ dan berbeda bermakna ( $p<0,05$ ), berarti infusun daun sirih $20 \%$ mempunyai efek antibakteri lebih kuat dari hidrogen peroksida $3 \%$. Infusum daun sirih mengandung minyak atsiri yang di dalamnya terdapat senyawa phenol yang bersifat bakterisid. ${ }^{10}$ Senyawa phenol apabila terjadi interaksi dengan dinding sel mikroorganisme akan terjadi denaturasi protein dan meningkatkan permeabilitas mikroorganisme. ${ }^{10}$ Interaksi antar mikroorganisme mengakibatkan perubahan keseimbangan muatan dalam molekul protein, sehingga terjadi perubahan struktur protein dan menyebabkan terjadinya koagulasi. Protein yang mengalami denaturasi dan koagulasi akan kehilangan aktivitas fisiologis sehingga tidak dapat berfungsi dengan baik. Perubahan struktur protein pada dinding sel bakteri akan meningkatkan permeabilitas sel sehingga pertumbuhan sel akan terhambat dan kemudian sel menjadi rusak. Selain itu senyawa kavikol memberikan bau yang khas pada daun sirih dan memiliki daya bunuh bakteri 5 kali lebih besar dari phenol. Senyawa kariofilen bersifat antiseptik dan anestetik lokal, sedangkan senyawa eugenol bersifat antiseptik dan analgesik topikal. 
Hidrogen peroksida merupakan larutan yang terbentuk dari reaksi asam sulfat dan barium peroksida. ${ }^{3}$ Hidrogen peroksida $3 \%$ apabila berinteraksi dengan darah, pus, serum, air liur dan bahan organik lainnya akan menghasilkan $\mathrm{H}_{2} \mathrm{O}+\mathrm{O}_{\text {nascent }}$. Efek tersebut mengangkat kotoran dalam saluran akar. Berdasarkan penguraian senyawa $\mathrm{H}_{2} \mathrm{O}_{2}$ menjadi $\mathrm{H}_{2} \mathrm{O}+\mathrm{O}_{\text {nascent }}$. Onascent yang timbul bersifat sementara, selanjutnya akan berubah menjadi $\mathrm{O}_{2}$. Gas oksigen yang terbentuk akan menghancurkan kuman anaerob beserta bahan yang dihasilkan. ${ }^{10}$ Daya antibakteri hidrogen peroksida 3\% kurang terhadap bakteri mix saluran akar karena sebagian besar bakteri dalam saluran akar bersifat fakultatif anaerob (Streptococcus Viridans) yang dapat hidup dengan atau tanpa adanya oksigen. Oleh karena itu oksigen dari hidrogen peroksida $3 \%$ tersebut tidak dapat membunuh bakteri mix.

Dari hasil penelitian ini dapat ditarik kesimpulan bahwa khasiat antibakteri infusum daun sirih $20 \%$ lebih baikdari hidrogen peroksida 3\% terhadap bakteri mix. Diharapkan infusum daun sirih dapat dimanfaatkan sebagai bahan irigasi.

\section{DAFTAR PUSTAKA}

1. Burnett GW, Schuster GS. Oral microbiology and infection disease. London: William and Wilkins; 1980. p. 62-66, 141-60.

2. Cohen S, Burns RC. Pathway of the pulp. $5^{\text {th }}$ ed. St Louis: Mosby Co; 2002. p. 123-47.

3. Grossman LI, Oliet S, Del Rio CE. Endodontic practic. $12^{\text {nd }}$ ed. Philadelphia: Lea and Febiger; 1995. p. 196-262.

4. Walton RE, Torabinejad M. Prinsip dan praktik ilmu endodonsia. Edisi II. Jakarta: Buku Kedokteran EGC; 1996. hal. 262-81.

5. Nicholls E. Cleaning and preparation of the pulp cavity, endodontic. $3^{\text {rd }}$ ed. 1988. p. $145-9$.

6. www.lembaga.wima.ac.id/ippm/ppot/isi, 2004.

7. Kartasaputra G. Budidaya tanaman berkhasiat obat. Edisi II. Jakarta: PT Rineksa Cipta; 1992. h. 25-26.

8. Darwis SN. Potensi sirih sebagai tanaman obat. Jogjakarta: Makalah dalam Seminar Sirih. Kelompok kerja nasional tanaman obat Indonesia. 1991.

9. Indah TS, Retno S, Ristanto. Pengaruh teknik penyimpanan daun sirih sebagai obat kumur terhadap akumulasi plak gigi dan pertumbuhan bakteri S Sanguis. Jogjakarta: Laporan penelitian: UGM; 1990.

10. Mieke HS, Yanti M, Razak U. Usaha pemeriksaan daya anti mikroba dan ekstrak daun sirih terhadap beberapa bakteri. Denpasar: Konas XVI. PDGI; 1985. 